\title{
Risk Matrix Model Applied to the Outsourcing of Logistics' Activities
}

\author{
Fouad Jawab, Jabir Arif \\ Sidi Mohamed Ben Abdellab University (Morocco) \\ jawabf@gmail.com,arifjabir@gmail.com
}

Received: April 2015

Accepted: September 2015

\section{Abstract:}

Purpose: This paper proposes the application of the risk matrix model in the field of logistics outsourcing. Such an application can serve as the basis for decision making regarding the conduct of a risk management in the logistics outsourcing process and allow its prevention.

Design/methodology/approach: This study is based on the risk management of logistics outsourcing in the field of the retail sector in Morocco. The authors identify all possible risks and then classify and prioritize them using the Risk Matrix Model. Finally, we have come to four possible decisions for the identified risks. The analysis was made possible through interviews and discussions with the heads of departments and agents who are directly involved in each outsourced activity.

Findings: It is possible to improve the risk matrix model by proposing more personalized prevention measures according to each company that operates in the mass-market retailing.

Originality/value: This study is the only one made in the process of logistics outsourcing in the retail sector in Morocco through Label'Vie as a case study. First, we had identified as thorough as we could all possible risks, then we applied the Risk Matrix Model to sort them out in an ascending order of importance and criticality. As a result, we could hand out to the decision-makers the mapping for an effective control of risks and a better guiding of the process of risk management.

Keywords: risk matrix model, logistics outsourcing, risk management, retail sector, Morocco 


\section{Introduction}

Today's competitive and demanding environment requires market participants to be more active, to focus on a more efficient organization and constantly innovate new approaches to stay ahead of their competitors. These players have made great efforts to increase their core competency by outsourcing some of their activities and limit their range of activity in those they master better. The reason for this first wave of outsourcing was then purely economic, based on cost criteria as showed in the research made by Gheeraert (2010).

Regarding logistics specifically, It found itself directly involved in the outsourcing process, and passed from the first phase of outsourcing, a logic driven flows, where the only issues were to transport and store, to a logical flow with more business oriented vision, making the consumer the Number One of their concerns.

On the other hand, we note that the studies that deal with outsourcing by adopting an approach based on risk management are relatively rare (Hon Kam, Chen \& Wilding, 2011; Tsai, Liao \& Han, 2008). As far as we are concerned, we will try to process the dimension of risk management in the context of logistics outsourcing, which is not a new dimension in the management, but it is a new and growing subject in the context of management supply chain (Lavastre, Gunasekaran \& Spalanzani, 2012).

It is in the core of this finding that our goal lays. This paper aims to adapt the modeling approach that focuses on the study and control of risks in the field of outsourcing logistics. We decided, in this paper, to address this issue by adopting an approach based on the modeling of risk management, before concluding by demonstrating our proposal through a validation over a concrete case. In the end, our work will lead to the development of an operational dashboard specifying arbitration elements and action plan as well as preventive measures.

\section{Context}

The context of industrial relations between enterprises has become more complex and turbulent (Hillman, 2006). In fact, to get into an outsourcing logistics process is an extremely important strategic act, because it is one of the main drivers for the creation of a new organizational form. According to Hallikas, Puumalainen, Vesterinen \& Virolainen (2005), logistics partnerships have become very complex and vulnerable to various types of risks (Hallikas et al., 2005). To Harland, Brenchley \& Walker (2003), this complexity results from different sources of risk, such as globalization, outsourcing, e-commerce, and consumer demands (Harland et al., 2003).

Thus, due to the increasing outsourcing of logistics activities, logistics service proves to be a relevant field of analysis for the study of inter-organizational relationships. These relationships 
are part of long-term stability and require a minimum number of mutual trust and an agreement between agents (Jawab, Driss \& Abdennebi, 2006).

This evolution of outsourcing has gradually changed the contours of Logistics Service Provider (LSP). These LSP fall into the category of third actors just as a consulting company and could accumulate not only the operationalization of mutualisation but also its management, in a strategic sense. However, despite the advantages and benefits of outsourcing logistics, many relationships are not renewed to the end of their contract or do not last until the initial term. Therefore, risk management has become a major concern in outsourcing (Waters, 2007).

\section{Issues and Research Interest}

Modeling of risk management in the context of logistics outsourcing is intended for the following reasons:

- Logistics partnerships have become very complex and vulnerable to various types of risks. This complexity results from different sources of risk, such as globalization, increasing complexity, outsourcing, e-commerce, and consumer demands.

- As a result, risk management has become a major concern in outsourcing.

- Although the literature is rich in theoretical models and empirical studies dealing with the outsourcing decision, its determinants, its success and failure factor, we note that the studies that deal with outsourcing by adopting a management approach based on the risk is relatively rare (Hon Kam et al., 2011).

- We want to look at this particular context by using the concept of modeling. This concept will be, for a decision maker, a diagnostic tool, a decision support tool and finally prioritization and planning of prevention actions and measures.

- Moreover, modeling is a means of assessment of risks related to the logistics outsourcing process to ensure a better performance evaluation and this by keeping a focus on the customer's satisfaction. 


\section{Modeling of Risk Management: The Case of LABEL'VIE}

\subsection{Modeling Risk Management in its Environment}

We used the SADT/IDEEFO tool to develop risk management as shown in Figure 1. Risk management is an activity that involves several categories of actors as experts from the field of study, experts of risk management, auditors, while using a set of resources. It transforms the knowledge of the study system and information about its operating environment decisions (objectives, guidelines and other constraints) and instructions for control or support systems. It also supplies knowledge bases in a spirit of corporate knowledge in the form of feedback.

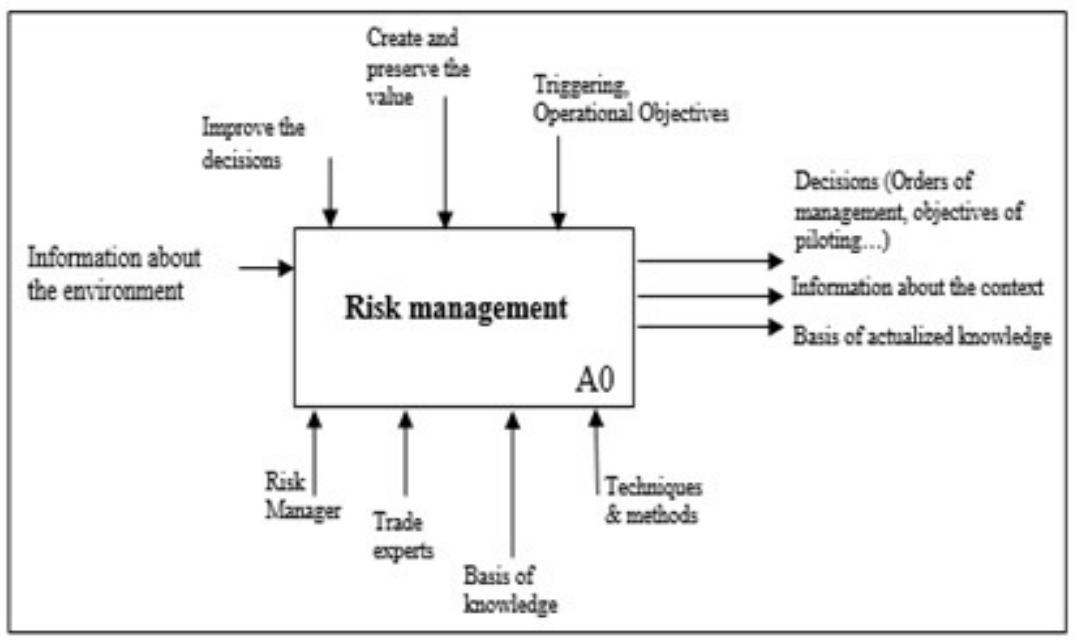

Figure 1 . The risk management - an external view

In developing this representation, we divided the "risk management" entity into four binders: "Context Framing" binder, "Risk assessment" binder, also divided into three stages (identification, analysis and evaluation), "Risk Processing" binder and finally "Risk monitoring" binder as shown in Figure 2.

- Context Framing: Frame the process of the risk management in setting the boundaries of the study by delimiting the environment and fundamental parameters.

- Risk assessment: divided into three stages:

- Risk identification: Identify the potential risks through developing an inventory of all risks situations.

- Risk Analysis: Characterize the risk and understand the operating procedure.

- Risk Evaluation: Assess the risks in terms of quantitative or qualitative scale and develop a prioritization of them in order to guide decisions towards the right treatment. 
- Risk processing: sets treatment options to change the value of the priority risks so that the overall level of risks is consistent with the risk adversity.

- Risk Monitoring: Observing the internal and external environment to understand the evolution of risks, and collect the information needed to update the records of risks.

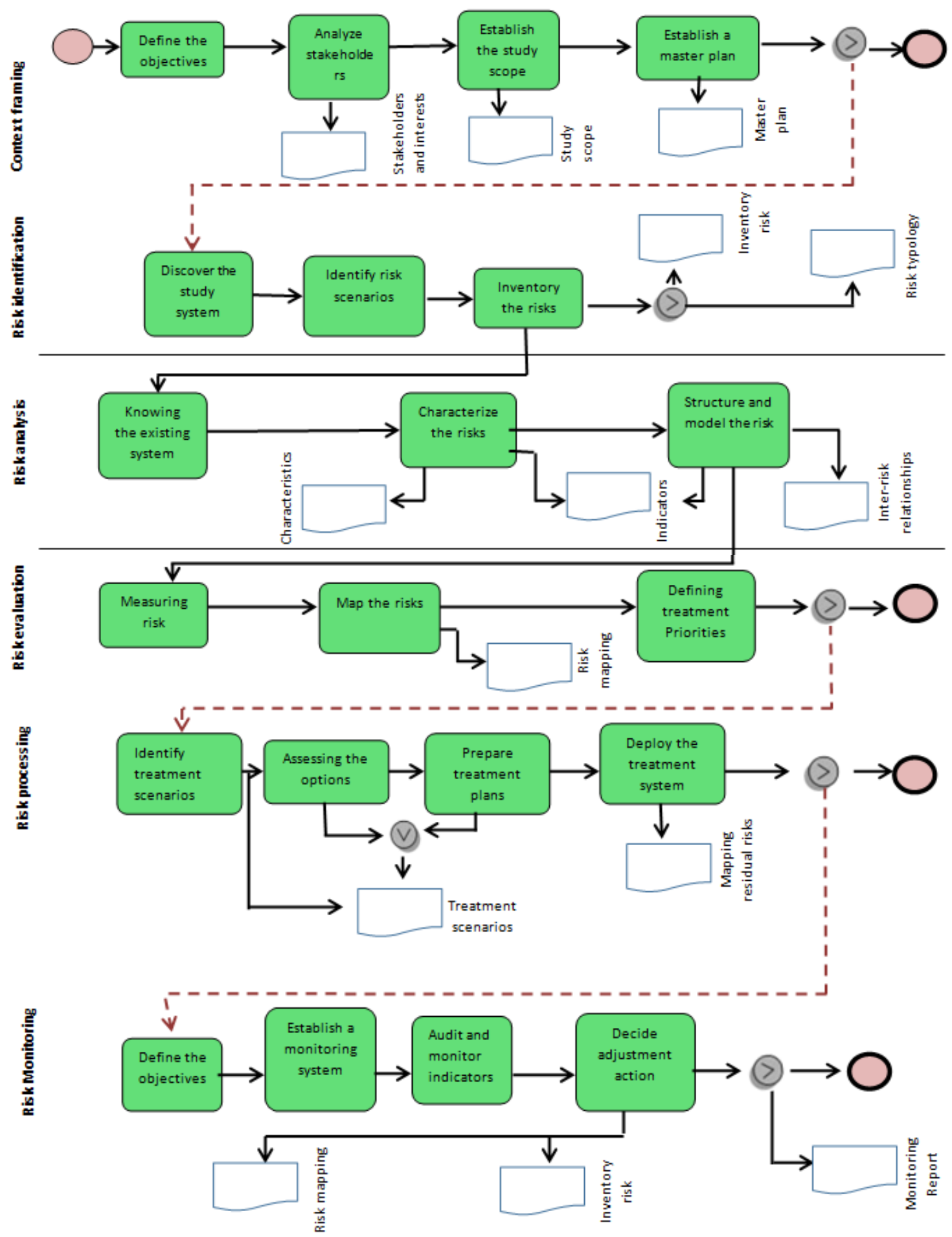

Figure 2. The modeling of the risk management process 


\subsection{The Life Cycle of the Outsourcing of Label'Vie}

Label'Vie SA is a limited company under Moroccan law. Its mission is the buying and selling, in the self-service form or any other form, of any item, food, and non-food consumer product. With the acquisition of Metro Cash \& Carry in 2011, the group Label'Vie covers now all forms of distribution. The surface of the Skhirate platform, the studied case, is spread over an area of 24,000 sqm. This area includes the cool and dry warehouse (APLS/Frozen + F\&L + Marée), plus the parking Lot area dedicated to unload trucks. The total storage capacity is 23,012 pallets; 19,316 pallets in height and 3,696 pallet picking.

Four processes characterize the main logistic activity in the Skhirate platform: receiving, storing, preparing and shipping. The LSP, IDLogistique, performs those activities during the deployment phase. The Figure 3 shows the life cycle of the logistics outsourcing process within Label'Vie as well as the third phase of the process where we want to apply the concept of the risk management.

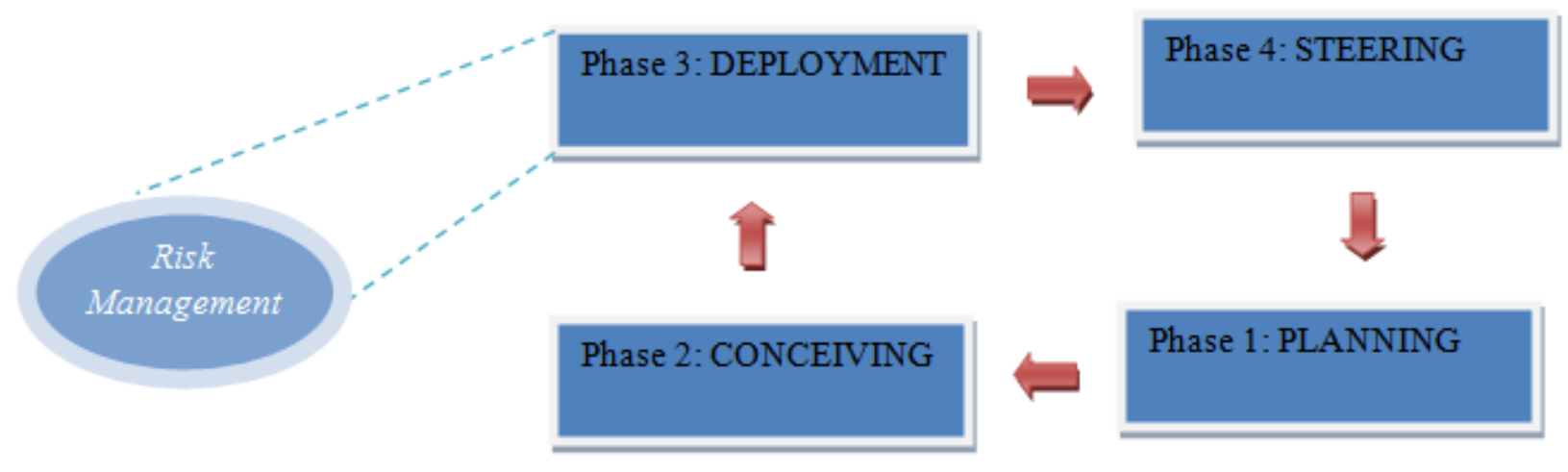

Figure 3. The Life cycle of the logistics outsourcing within Label'Vie

For a wider approach, we will firstly model the logistics outsourcing process as shown in the figure below. 


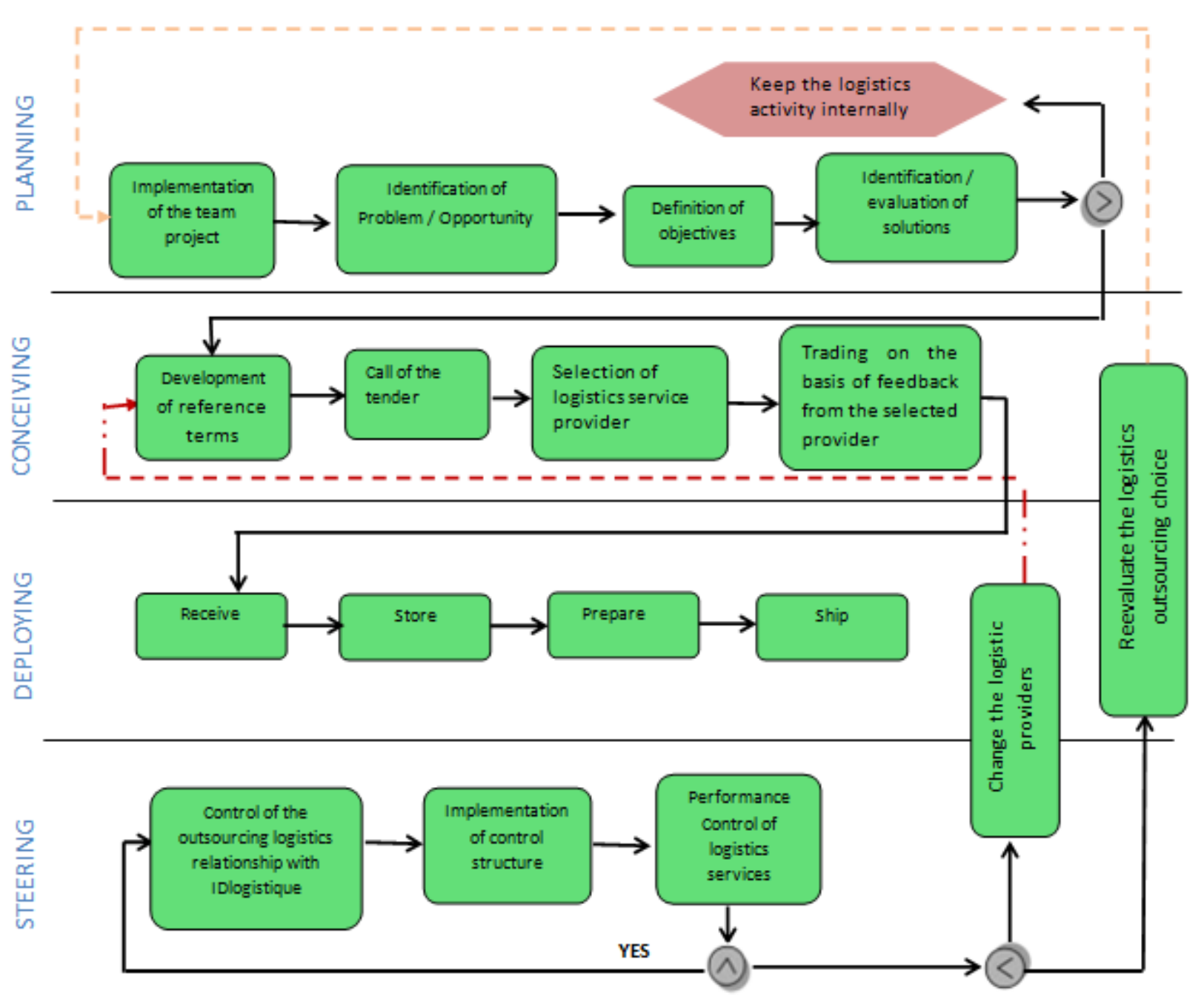

Figure 4. The modeling of logistics outsourcing process

The planning stage sets goals and a master plan. It sets up a team of officials from the platform to conduct the outsourcing procedure by defining the objectives of outsourcing their warehouse and evaluating the decision to keep the activity of internal storage. The design stage is characterized by collaboration between each manager in order to define a structure and modes of operation. Indeed, this stage is to develop the specifications and choosing the right provider at the base of criteria. The deployment is the phase where the service provider IDL manages the warehouse of Label'Vie namely: receiving, storing, preparing and shipping.

Finally, the steering stage is the implementation of dashboards to assess the capacity of IDL to deliver a service that meets the specifications defined in the contract. When the contract expires, Label'Vie can renegotiate and renew the contract with IDL. Otherwise, there are two options available:

- Reevaluate the choice to outsource by re-planning the process again (restarting from the planning phase). 
- Deciding to continue to outsource its logistics function but changing the service provider (restarting from the design stage).

Note that the first two phases (Planning, conceiving) have already been completed within the platform, so we agreed and after consulting the head of the platform to model the risk management of the "Deploying" phase (figure below), carried out by the IDL service provider and subject of the study.

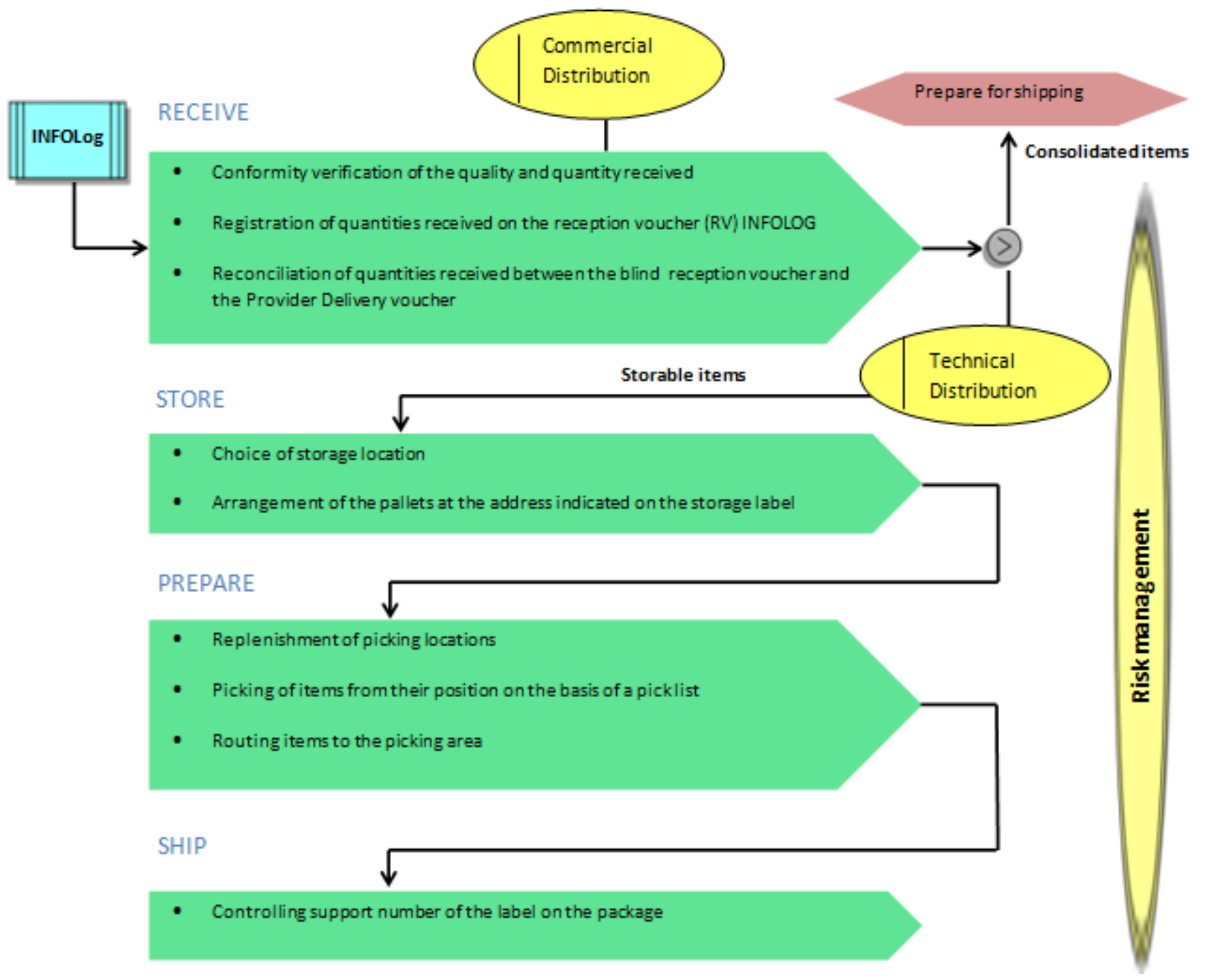

Figure 5. The modeling of "Deploying" phase

\subsection{Discussions}

We conducted an analysis of the risk management of logistics outsourcing in the retail sector in Morocco through Label'Vie as a case study with the service provider IDLogistique. At the basis of this modelling and incorporating the "risk management" dimension at the phase 3 of the outsourcing process, the analysis revealed the potential risks that could affect the outsourcing 
relationship, through interviews and discussions with managers and staff directly involved in each activity.

Applying our model gave way to dividing of the outsourced service into sub-processes. This led to identify areas of risk that should be monitored.

Thus, we proposed a risk matrix (see Table 1) validated with the head of the platform and the head of control and steering department as well as the various stakeholders in each activity. This matrix summarizes the risks posed, the description of each risk and its corresponding activity.

\begin{tabular}{|c|c|c|}
\hline Activity & Risk & Description \\
\hline \multirow{4}{*}{ Receipt } & $\begin{array}{l}\text { Receiving unsolicited or } \\
\text { erroneous articles }\end{array}$ & Risk of receiving unordered articles or articles with incorrect barcodes. \\
\hline & Receipt error & $\begin{array}{l}\text { Number of items approved does not match the quantity shown on the } \\
\text { delivery slip. }\end{array}$ \\
\hline & \multirow[t]{2}{*}{ Delivery condition } & $\begin{array}{l}\text { Failure risk of the supplier in deadline and / or quality, } \\
\text { unprofessionalism, non-conformity of the goods received according to } \\
\text { the standard packaging, status of delivery trucks, etc... }\end{array}$ \\
\hline & & $\begin{array}{l}\text { Bulk delivery which results in additional costs to the platform } \\
\text { (temporary, stretch film ...) }\end{array}$ \\
\hline \multirow{6}{*}{ Storage } & $\begin{array}{l}\text { Expiry date for } \\
\text { consumption }\end{array}$ & Receiving items with near expiration dates \\
\hline & Referencing articles & $\begin{array}{l}\text { Risk of non-attachment of bar code of articles (ex: change in the bar } \\
\text { code by the supplier) }\end{array}$ \\
\hline & Out of stock & $\begin{array}{l}\text { Risk of disruption due to delivery delays or exceptional provider } \\
\text { command, provider is in disruption, increasing prices for items. }\end{array}$ \\
\hline & Overstock & $\begin{array}{l}\text { Risk of stock excess related to a decline in orders from stores, } \\
\text { constitution of stocks in anticipation and an ineffective flow } \\
\text { management, etc... }\end{array}$ \\
\hline & Storage condition & $\begin{array}{l}\text { Risk related to the organization within the platform, addressing } \\
\text { problem, lack / connection error at the SI, misplacement, etc... }\end{array}$ \\
\hline & $\begin{array}{l}\text { Non-filling the warehouse } \\
\text { (financial risk) }\end{array}$ & $\begin{array}{l}\text { Mismanagement of supplies, non-availability of items from suppliers, } \\
\text { delay placing orders ... etc. }\end{array}$ \\
\hline \multirow[t]{2}{*}{ Preparation } & $\begin{array}{l}\text { activity volume / } \\
\text { destination exceeds truck } \\
\text { capacity (planning) }\end{array}$ & $\begin{array}{l}\text { Inadequate coordination with transportation service that can lead to a } \\
\text { mobilization of space, risk of theft (exchange items not loaded with } \\
\text { those damaged on the stock) }\end{array}$ \\
\hline & Errors in shipments & $\begin{array}{l}\text { Risk of error in the preparations sent to stores (error location of } \\
\text { supports) }\end{array}$ \\
\hline \multirow{3}{*}{ Expedition } & Damaged shipment & $\begin{array}{l}\text { Risk of damaged shipment due to a misuse of product during the } \\
\text { journey to the store, non-optimal preparation, } \\
\text { case of unsecured transport, }\end{array}$ \\
\hline & $\begin{array}{l}\text { The rest in preparation } \\
\text { areas after loading the } \\
\text { trucks }\end{array}$ & $\begin{array}{l}\text { Risk is in port linked to an estimation error of tonnage, rush orders, } \\
\text { special orders, etc... }\end{array}$ \\
\hline & Late delivery to stores & $\begin{array}{l}\text { Risk of delayed supply shops, forgetfulness / lack of order processing, } \\
\text { order not down at the system level (order valued but not sent). }\end{array}$ \\
\hline $\begin{array}{l}\text { Monitoring \& } \\
\text { Control }\end{array}$ & $\begin{array}{l}\text { Contractual failure in } \\
\text { logistics discounts }\end{array}$ & $\begin{array}{l}\text { Risk that the discount logistics are not contracted, including those } \\
\text { relating to historical suppliers. }\end{array}$ \\
\hline \multirow{3}{*}{ Internal } & $\begin{array}{l}\text { Lack of communication of } \\
\text { volume with purchases } \\
\text { service }\end{array}$ & $\begin{array}{l}\text { Risk associated with non-compliance with volumes such as negotiated } \\
\text { by purchases service (purchases forecast is largely disconnected from } \\
\text { the forecast of stores). }\end{array}$ \\
\hline & $\begin{array}{l}\text { Risk security } \\
\text { (Personal/means) }\end{array}$ & $\begin{array}{l}\text { Risk personnel security at the platform (safety device, handling } \\
\text { equipment, etc.). }\end{array}$ \\
\hline & Diversion / theft & Risk of diversion / theft of goods at the platform \\
\hline \multirow[t]{2}{*}{$\begin{array}{l}\text { Information } \\
\text { System (IS) }\end{array}$} & $\begin{array}{l}\text { Exchange of information } \\
\text { between the GOLD } \\
\text { system (Labelvie) and } \\
\text { INFOLOG (provider } \\
\text { IDlogistique) }\end{array}$ & $\begin{array}{l}\text { Risk of late / no exchange of information between GOLD and INFOLOG } \\
\text { can cause loss of information, ineffective monitoring, etc.. }\end{array}$ \\
\hline & Network failure & $\begin{array}{l}\text { Risk of network outage that may impact the functioning of the } \\
\text { platform operating system }\end{array}$ \\
\hline
\end{tabular}

Table 1. Risk of outsourcing logistics (Label'Vie case) 
By analysis of the conversations realized in the platform to decompose the information, we tried to detect the risks expressed by the various actors and having a direct impact on the platform.

The results of this analysis are then transformed into corresponding expressions with the notion of the risk that allowed highlighting a list of twenty risks.

With the aim of gathering these risks, we based mostly on the existing homogeneity between the risks regarding their contents, their definition and their meaning. They are typically categorized according to seven classes of activities (see Table 1).

In order to figure out the most critical risk, we scaled them according to the importance and criticality degree. Thus, to eliminate the most likely risk and hand out to the head of the platform the final dashboard.

\subsection{The Risk Matrix Model}

The risk matrix model (RMM) is a type of risk assessment model, which is implemented by the Air Force Electronic System Center (ESC) of the American team of engineering and supply (Libo, 2007). It is widely used to identify risks, estimate their probability of occurrence and impact, and rank the risks based on this information. Risk Matrix Model also provides a capability for documenting how these risks will be handled(action plans) and tracking the effect of this action on associated risks (Zhao \& Zhang, 2005).

The need to use the RMM is highly recommended with a view to identify the most critical risks and how to allocate resources to eliminate the most likely ones. We can, through the RMM, identify risk factors, including risk sources, the expected probability, rank the level of risk, and ultimately provide a mapping for an effective control of risk and guide better the process of risk management. This method is simple and combined with both qualitative and quantitative analysis.

In the RMM, we will adopt the consultation of agents directly involved in each activity outsourced, based on their experiences, to identify and arrest the impact and probability of risks. Then calculate the ranking of all the risks, design and provide to the decision makers the final scheme with action plan and specific measures to reduce the risks of logistics outsourcing.

\subsubsection{The Implementation of the RMM}

Based on the risk matrix model, the criticality of the risk is based on the assessment of two parameters: The impact that evaluates the consequences on the platform and the probability 
of occurrence that assesses the uncertainty of the occurrence of the risk. We have identified five criteria for both impact and probability of the risk as shown in the Table 2 and Table 3.

\begin{tabular}{|c|l|}
\hline Risk Impact & \multicolumn{1}{|c|}{ Description } \\
\hline Critical & Critical risk goes directly to the project failure \\
\hline Serious & Serious risk lead to a significant decrease in indicators of project objectives \\
\hline Moderate & The project was moderately affected, but part of the project objectives can be achieved \\
\hline Minor & The project was slightly affected, but could meet the objectives \\
\hline Negligible & risk has had almost no effect on project objectives \\
\hline
\end{tabular}

Table 2. Impact of risk (I)

\begin{tabular}{|c|l|}
\hline Risk Probability & Description \\
\hline $0-10 \%$ & Almost impossible \\
\hline $11 \%-40 \%$ & Unlikely \\
\hline $41 \%-60 \%$ & Can occur in the implementation \\
\hline $61 \%-90 \%$ & Likely to occur \\
\hline $91 \%-100 \%$ & Almost certainly going to happen \\
\hline
\end{tabular}

Table 3. Probability of risk (P)

We established the level of impact and probability of the risk in both coordinate systems to obtain the table of risk level, as shown in Table 4.

\begin{tabular}{|c|c|c|c|c|c|}
\hline \multicolumn{1}{c|}{} & \multicolumn{5}{c|}{ Impact } \\
\hline Probability & Negligible & Minor & Moderate & Serious & Critical \\
\hline $\mathbf{0 - 1 0} \%$ & $\mathrm{~L}$ & $\mathrm{~L}$ & $\mathrm{~L}$ & $\mathrm{M}$ & $\mathrm{M}$ \\
\hline $\mathbf{1 1} \%-\mathbf{4 0} \%$ & $\mathrm{~L}$ & $\mathrm{~L}$ & $\mathrm{M}$ & $\mathrm{M}$ & $\mathrm{H}$ \\
\hline $\mathbf{4 1 \%} \% \mathbf{- 6 0} \%$ & $\mathrm{~L}$ & $\mathrm{M}$ & $\mathrm{M}$ & $\mathrm{M}$ & $\mathrm{H}$ \\
\hline $\mathbf{6 1 \% - 9 0 \%}$ & $\mathrm{M}$ & $\mathrm{M}$ & $\mathrm{M}$ & $\mathrm{M}$ & $\mathrm{H}$ \\
\hline $\mathbf{9 1 \% - 1 0 0 \%}$ & $\mathrm{M}$ & $\mathrm{H}$ & $\mathrm{H}$ & $\mathrm{H}$ & $\mathrm{H}$ \\
\hline
\end{tabular}

Note: H (High), M (Medium), L (Low)

Table 4. Level -Impact- Probability of the risk (LIP)

Finally, the RMM recommends applying the Borda method to help us identifying the principal one.

Borda method: is used in the Risk Matrix Model to rank risks from most-to-least critical on, on basis of multiple evaluation criteria (Sha, Hangjun \& Yezhi, 2011).

Borda proposed the following voting method: Given $\mathrm{N}$ candidates, if points of $\mathrm{N}-1, \mathrm{~N}-2, \ldots$, and 0 are assigned to the first-ranked, second-ranked, ..., and last-ranked candidate in each voter's preference order, then the winning candidate is the one with the greatest total number of points. Instead of voters, suppose that there are multiple criteria (Virginie, Favardin \& Lepelley, 2009). 
If $\mathrm{R}_{\mathrm{ik}}$ is the rank of the risk $\mathrm{i}$ under criterion $\mathrm{k}$, the Borda factor of the risk " $\mathrm{i}$ " is given by:

$$
b_{i}=\sum_{i=1}^{\mathrm{n}}\left(\mathrm{N}-R_{i k}\right)
$$

Let $\mathrm{N}$ be the total number of risks, and the index $\mathrm{i}$ denote a particular risk. Let the impact assessment be denoted by $\mathrm{k}=1\left(R_{i}\right)$, and the probability assessment be denoted by $\mathrm{k}=2\left(R_{p}\right)$.

$$
b_{i}=\left(\mathrm{N}-R_{i}\right)+\left(\mathrm{N}-R_{p}\right)
$$

The terms $R_{i}$ and $R_{p}$ are calculated as follows:

$$
\begin{gathered}
R_{i}=\frac{1}{2} *(2 * C i+1+M i) \\
C i=\sum_{r=1}^{i-1} \mathrm{Mr} ; \quad C_{i=1}=0 ; \quad i>1 \\
R_{p}=\frac{1}{2} *(2 * C p+1+M p) \\
C p=\sum_{r=1}^{p-1} \mathrm{Mr} ; \quad C_{p=1}=0 ; \quad p>1
\end{gathered}
$$

Mi is the number of risks, which have the same impact (I) and Mp are the number of risks which have the same probability $(P)$.

\subsubsection{Application of the RMM to the Process of the Logistics Outsourcing in Label'Vie}

To construct the matrix of the risks, we proceeded to the interviews with 16 team leaders including the head of the platform and the head of control department. Then we conceived the risk matrix model, which consists of the column of the risks, the column of the impact and the column of the probability. These two last ones are judged and filled by the heads of departments and the interviewed agents. We then applied the Borda method according to the systems (1, 2 and 3$)$.

The value of Borda factor (bi) found in the Table 5 indicates the number of the most critical risks in order of criticality. According to the Borda method, the lowest value of the FB corresponds to the most important risk and if the value of the FB is equal to zero it means that the corresponding risk is the most critical one.

Therefore, the risks $\mathrm{N}^{\circ} 1$ and $\mathrm{N}^{\circ} 10$ have the same Borda factor (bi) thus they are classified in position 0 . The risks $N^{\circ} 6$ and $N^{\circ} 13$ have the ranking 2 because there are two other risks which are more critical. The risk $N^{\circ} 7$ has the position 4 because there are 4 other risks which 
are more critical and so on. In the end, we proposed an operational dashboard specifying arbitration elements and action plan as well as preventive measures as shown in the final model (see Table 5) to help the platform to adapt itself to the change and to find a set of ways of adjustment in every situation of risk.

Consequently, this approach multi-criterion has one main characteristic and which is the fact that it formalizes (or model) the preparation of the decisions. First of all, it improves the transparency of the process of decision. Then, it defines, specifies and highlights the responsibility of the decision-maker.

\begin{tabular}{|c|c|c|c|c|c|c|c|c|c|c|c|}
\hline$N^{\circ}$ & Risk & I & P (\%) & LIP & Mi & Mp & $\mathbf{R i}$ & $\mathbf{R p}$ & bi & ranking & Action plan \\
\hline 1 & $\begin{array}{l}\text { Receiving } \\
\text { unsolicited or } \\
\text { erroneous } \\
\text { articles }\end{array}$ & Serious & $91-100$ & $\mathrm{E}$ & 12 & 4 & 6.5 & 6.5 & 27 & 0 & $\begin{array}{l}\text { - The receipt must be made on } \\
\text { the basis of a customer orders } \\
\text { copy }\end{array}$ \\
\hline 2 & Receipt error & Serious & $61-90$ & $E$ & 12 & 6 & 18.5 & 7.5 & 14 & 15 & $\begin{array}{l}\text { - Blind counting. } \\
\text { - Back office rapprochement } \\
\text { (administrative agent) }\end{array}$ \\
\hline 3 & $\begin{array}{l}\text { Delivery } \\
\text { condition }\end{array}$ & Critical & $61-90$ & $E$ & 4 & 6 & 14.5 & 9.5 & 16 & 12 & $\begin{array}{l}\text { - Hold regular meetings } \\
\text { ( } 1 / \text { month) with the top } 10 \\
\text { suppliers to evaluate their } \\
\text { performance and engage them } \\
\text { on penalties for non- } \\
\text { compliance with service level } \\
\text { agreed at these meetings }\end{array}$ \\
\hline 4 & $\begin{array}{l}\text { Expiry date for } \\
\text { consumption }\end{array}$ & Serious & $41-60$ & $\mathrm{E}$ & 12 & 3 & 10.5 & 8 & 21.5 & 5 & $\begin{array}{l}\text { - Provide to receptionists } \\
\text { supports indicating deadlines } \\
\text { consumption to tolerate when } \\
\text { receiving. }\end{array}$ \\
\hline 5 & $\begin{array}{l}\text { Referencing } \\
\text { articles }\end{array}$ & $\begin{array}{c}\text { Moderat } \\
\mathrm{e}\end{array}$ & $11-40$ & M & 3 & 7 & 14 & 7 & 19 & 10 & $\begin{array}{l}\text { - Require to the provider to } \\
\text { notify Label'Vie of any change } \\
\text { of bar code and apply penalties } \\
\text { for non-compliance }\end{array}$ \\
\hline 6 & Out of stock & Critical & $11-40$ & $E$ & 4 & 7 & 5.5 & 11 & 23.5 & 2 & $\begin{array}{l}\text { - Identify the actual cause of } \\
\text { the failure and apply } \\
\text { appropriate corrective action } \\
\text { as appropriate. } \\
\text { - Update procedures to } \\
\text { compensate for any cause } \\
\text { behind the risk of rupture (eg, } \\
\text { exceptional control, increasing } \\
\text { price ...) }\end{array}$ \\
\hline 7 & Overstock & Critical & $11-40$ & $\mathrm{E}$ & 4 & 7 & 6.5 & 11 & 22.5 & 4 & $\begin{array}{l}\text { - Have a stock management } \\
\text { pattern that instantly shows } \\
\text { the relationship between the } \\
\text { real-time stock available and } \\
\text { demand changes } \\
\text { - Hold follow-up meetings with } \\
\text { the procurement department. }\end{array}$ \\
\hline 8 & $\begin{array}{l}\text { Storage } \\
\text { condition }\end{array}$ & Serious & $91-100$ & $E$ & 12 & 4 & 10.5 & 9.5 & 20 & 6 & $\begin{array}{l}\text { - Update and improve the } \\
\text { traceability system stock, avoid } \\
\text { errors in preparation and } \\
\text { delivery of items, awareness } \\
\text { and monitoring of storage } \\
\text { agents }\end{array}$ \\
\hline 9 & $\begin{array}{l}\text { Non-filling the } \\
\text { warehouse } \\
\text { (financial risk) }\end{array}$ & Minor & $61-90$ & M & 1 & 6 & 13 & 7.5 & 19.5 & 9 & $\begin{array}{l}\text { - Provide a list of suppliers to } \\
\text { contact in case of failure of } \\
\text { principal suppliers. }\end{array}$ \\
\hline 10 & $\begin{array}{l}\text { activity } \\
\text { volume / } \\
\text { destination } \\
\text { exceeds truck } \\
\text { capacity } \\
\text { (planning) }\end{array}$ & $\begin{array}{c}\text { Moderat } \\
\mathrm{e}\end{array}$ & $11-40$ & M & 3 & 7 & 3 & 10 & 27 & 0 & $\begin{array}{l}\text { - Communicate at Day - } 1 \text { the } \\
\text { shipping forecast to the } \\
\text { transport service to provide the } \\
\text { necessary logistics } \\
\text { - Provide more providers for } \\
\text { the transport operation. }\end{array}$ \\
\hline
\end{tabular}




\begin{tabular}{|c|c|c|c|c|c|c|c|c|c|c|c|}
\hline $\mathbf{N}^{\circ}$ & Risk & $\mathbf{I}$ & P (\%) & LIP & Mi & Mp & $\mathbf{R i}$ & $\mathbf{R p}$ & bi & ranking & Action plan \\
\hline 11 & $\begin{array}{l}\text { Errors in } \\
\text { shipments }\end{array}$ & Serious & $61-90$ & E & 12 & 6 & 9.5 & 10.5 & 20 & 6 & $\begin{array}{l}\text { - Provide a post preparation } \\
\text { control to ensure that items } \\
\text { shipment correspond to } \\
\text { delivery slip. Include in the } \\
\text { control the verification of the } \\
\text { destination. } \\
\text { - Claim of stores within } 24 \\
\text { hours. }\end{array}$ \\
\hline 12 & $\begin{array}{l}\text { Damaged } \\
\text { shipment }\end{array}$ & Critical & $91-100$ & $E$ & 4 & 4 & 14.5 & 8.5 & 17 & 11 & $\begin{array}{l}\text { - Plan to include expenses to } \\
\text { the transport provider related } \\
\text { to breakage during transport } \\
\text { operation. } \\
\text { - Provide a spot check on } \\
\text { receipt of delivery to the store. }\end{array}$ \\
\hline 13 & $\begin{array}{l}\text { The rest in } \\
\text { preparation } \\
\text { areas after } \\
\text { loading the } \\
\text { trucks }\end{array}$ & Serious & $41-60$ & E & 12 & 3 & 10.5 & 6 & 23.5 & 2 & $\begin{array}{l}\text { - Communicate at Day }-1 \text { the } \\
\text { shipping forecast to the } \\
\text { transport service to provide the } \\
\text { necessary logistics }\end{array}$ \\
\hline 14 & $\begin{array}{l}\text { Late delivery } \\
\text { to stores }\end{array}$ & Serious & $11-40$ & $\mathrm{E}$ & 12 & 7 & 18.5 & 7 & 14.5 & 14 & $\begin{array}{l}\text { - Provide regular delivery } \\
\text { schedule containing all stores. } \\
\text { - Provide a support system } \\
\text { which allows to estimate the } \\
\text { commands based on historical } \\
\text { statistics and compare them } \\
\text { with the commands received. } \\
\text { - Provide back-up trucks by } \\
\text { region. }\end{array}$ \\
\hline 15 & $\begin{array}{l}\text { Contractual } \\
\text { failure in } \\
\text { logistics } \\
\text { discounts }\end{array}$ & Serious & $11-40$ & E & 12 & 7 & 18.5 & 11 & 10.5 & 19 & $\begin{array}{l}\text { - Provide a standard model of } \\
\text { logistics contracts indicating all } \\
\text { the elements to be agreed in } \\
\text { the contract. }\end{array}$ \\
\hline 16 & $\begin{array}{l}\text { Lack of } \\
\text { communicatio } \\
\mathbf{n} \text { of volume } \\
\text { with } \\
\text { purchases } \\
\text { service }\end{array}$ & $\begin{array}{l}\text { Moderat } \\
\mathrm{e}\end{array}$ & $11-40$ & M & 3 & 7 & 14 & 11 & 15 & 13 & $\begin{array}{l}\text { - Make shops aware to be } \\
\text { engaged in more commands. }\end{array}$ \\
\hline 17 & $\begin{array}{l}\text { Risk security } \\
\text { (Personal/me } \\
\text { ans) }\end{array}$ & Serious & $61-90$ & $E$ & 12 & 6 & 9.5 & 10.5 & 20 & 6 & $\begin{array}{l}\text { - Update and ensure } \\
\text { compliance with safety } \\
\text { procedures within the platform. }\end{array}$ \\
\hline 18 & $\begin{array}{l}\text { Diversion / } \\
\text { theft }\end{array}$ & Serious & $91-100$ & $E$ & 12 & 4 & 18.5 & 8.5 & 13 & 18 & $\begin{array}{l}\text { - Evaluate the security system } \\
\text { of the platform and intervene } \\
\text { when necessary. }\end{array}$ \\
\hline 19 & $\begin{array}{l}\text { Exchange of } \\
\text { information } \\
\text { between the } \\
\text { GOLD system } \\
\text { (Labelvie) and } \\
\text { INFOLOG } \\
\text { (provider } \\
\text { IDlogistique) }\end{array}$ & Serious & $61-90$ & $E$ & 12 & 6 & 18.5 & 7.5 & 14 & 15 & $\begin{array}{l}\text { - Integrate into the interfacing } \\
\text { system (batch control) to } \\
\text { ensure the exchange of } \\
\text { information flow between } \\
\text { GOLD and INFOLOG. }\end{array}$ \\
\hline 20 & $\begin{array}{l}\text { Network } \\
\text { failure }\end{array}$ & Serious & $41-60$ & $E$ & 12 & 3 & 18.5 & 8 & 13.5 & 17 & $\begin{array}{l}\text { - Provide a special procedure in } \\
\text { case of network failure } \\
\text { - Installation of a secondary } \\
\text { network (must be able to take } \\
\text { over in case of failure of the } \\
\text { primary network). }\end{array}$ \\
\hline
\end{tabular}

Table 5. Final Risk Matrix Model

\section{Conclusion}

The retail sector corresponds to the sector of the retail trade of consumer goods. It is inevitably accompanied by the risks of the various logistics outsourcing. Therefore, the effective management of the risks has a big strategic importance for a successful process of 
outsourcing; a reflection on a risk management approach to the logistics outsourcing seems quite relevant.

In this paper, we succeeded to have a more personalized approach called MODLOP-RMM. This latter gave way to MODeling the Logistics Outsourcing Process that led us to identify all the risk events on one hand. And the other hand to scale them by applying the Risk Matrixto give to the decision-makers a mapping for an effective and sharp control of risk and to guide better the process of risk management in the field of the retail sector.

The launching of the MODLOP-RMM in Skhirate platform was a first experience that demonstrates that it is suitable to any enterprise operating in the retail sector. The result of this experience was clear evidence that it was a plus in dealing with the different risks any enterprise can face due to the daily diversified and complex tasks performed. Therefore, we found out that it is more relevant to adopt the MODLOP-RMM approach.

For the managers, the approach has become a decision making tool to better guide the risk management process.

Methodologically speaking, this work ties up the melting of two main aspects; the development of the tools helping to the right decision and the problems related to the field of management science.

In this context, we were able to associate between two fields in management science as the logistics outsourcing process and the risk management. Based on the combination of these two fields, we were able to build an interface to move from a mere vision that scrutinizes the decision to a vision that leads to a more appropriate decision making.

Theatrically speaking, this paper made out more valuable the aspect of the Risk Management, which was formerly neglected in most studies analyzing the decisions of logistics outsourcing.

\section{References}

Gheeraert, R. (2010). Le phénomène de l'externalisation logistique au jourd'hui en France et le positionnement stratégique des prestataires de services logistiques en étroite synergie avec les industriels à travers des partenariats forts. Mémoire de fin d'études. Université Paris1, Septembre.

Hallikas, J., Puumalainen, K., Vesterinen, T., \& Virolainen, V.M. (2005). Risk-Based Classification of Supplier Relationships. Journal of Purchasing and Supply Management, 11(2-3), 72-82. http://dx.doi.org/10.1016/j.pursup.2005.10.005 
Harland, C., Brenchley, R., \& Walker, H. (2003). Risk in Supply Network. Journal of Purchasing \& Supply Management, 9(2), 51-62. http://dx.doi.org/10.1016/S1478-4092(03)00004-9

Hillman, M. (2006). Strategies for Managing Supply Chain Risk. Supply Chain Management Review, juillet-août, 11-13.

Hon Kam, B., Chen, L., \& Wilding, R. (2011). Managing Production Outsourcing Risks in China's Apparel Industry: A Case Study of Two Apparel Retailers. Supply Chain Management: An International Journal, 16(6), 428-445. http://dx.doi.org/10.1108/13598541111171147

Jawab, F., Driss, B., \& Abdennebi, T. (2006). Le réapprovisionnement continu dans les réseaux industriels, vers une meilleure gestion des interfaces de la supply chain. La Revue des Sciences de Gestion 2006/2, 218, 123-137.

Lavastre, O., Gunasekaran, A., \& Spalanzani, A. (2012). Supply Chain Risk Management in French Companies. Decision Support Systems, 52(4), 828-838.

http://dx.doi.org/10.1016/j.dss.2011.11.017

Libo, Z. (2007). The risk distribution study in the life-cycle of the outsourcing project. Beijing University of Chemical Technology.

Sha, F., Hangjun, Z., \& Yezhi, X. (2011). The Application of a Risk Matrix Method on Campus Network System Risk Assessment. International Conference on Communication Software and Networks - ICCSN, Xi'an, 27-29 May 2011, IEEE, 474-478.

Tsai, M., Liao, C., \& Han, C. (2008). Risk perception on logistics outsourcing of retail chains: model development and empirical verification in Taiwan. Supply Chain Management: An International Journal, 13(6), 415-424. http://dx.doi.org/10.1108/13598540810905679

Virginie, B., Favardin, P., \& Lepelley, D. (2009). La manipulation stratégique des règles de vote: une étude expérimentale. Recherches économiques de Louvain, 75.2009(4), 503-517.

Waters, D. (2007). Supply Chain Risk Management: Vulnerability and Resilience in Logistics. London and Philadelphia: Kogan Page.

Zhao, P., \& Zhang, X. (2005). Risk Assessment Method Of ERP Based on Risk Matrix. Informalization of Manufacturing Industry, 13(2), 87-88. 